\title{
Sustainable approach for biodiesel production and wastewater treatment by cultivating Pleusrastrum insigne in wastewater
}

Michael Van Lal Chhandama

Jain University

Kumudini Belur Satyan ( $\nabla$ kumudini.satyan.ju@gmail.com )

Jain University

\section{Research Article}

Keywords: Bioenergy, Microalgae, Pleurastrum insigne, Wastewater treatment, Biodiesel, Biofuel

Posted Date: January 18th, 2022

DOI: https://doi.org/10.21203/rs.3.rs-1186977/v1

License: (c) (1) This work is licensed under a Creative Commons Attribution 4.0 International License.

Read Full License 


\section{Abstract}

The globalized modern world has been confronted with some of the most challenging problems, most of which arises from human activities. Overexploitation of fossil fuels which leads energy and environmental crisis, loss of aquatic ecosystem due to improper disposal of household and industrial waste into water bodies constitute some of the biggest emerging global problems. In this study, an unconventional and sustainable approach to produce biodiesel was analyzed by growing Pleurastrum insigne in wastewater. The growth of P.insigne in wastewater in turn significantly reduce the amount of biological oxygen demand, total phosphorus content and total nitrogen content in the wastewater. Production of biodiesel conforming to international standards was predicted from $P$. insigne cultivated in wastewater confirming the effectiveness of combining wastewater treatment and biodiesel production.

\section{Introduction:}

The current trend of urbanization, industrialization, and alarming increase in population has led to an intensifying demand for clean energy and water supply (Ansari et al. 2017). The main source of energy for production industries and transportation, fossil fuels, has become a limited resource in addition to the production of harmful greenhouse gases (David 2018; Padmanabhan et al. 2012). The UN Report has mandated the reduction of fossil fuel production by $\sim 6 \%$ between 2020 and 2030 to mitigate global warming (UNEP 2020). Third-generation biofuels, derived from microalgae, have been proposed to be a potential substitute to conventional fossil fuels (Paddock et al. 2020). Microalgae are effective $\mathrm{CO}_{2}$ sequesters with a high propagation and lipid accumulation (Tariyal et al. 2013). The lipid produced by microalgae consisted of triglycerides that can be converted to fatty acids methyl esters (biodiesel) by transesterification (Hossain et al. 2008; Yadav et al. 2019). Studies have shown that microalgal biodiesel is non-toxic (contains no sulphur), biodegradable, releases significantly lesser greenhouse gases than other competing biofuels reducing the release of carbon monoxide, hydrocarbons, and particulate matter into the atmosphere (Zabed et al. 2019; Murphy et al. 2019; Ananthi et al. 2021). However, there has been concern over the expense involving biofuel production attributed by the high cost of growing and harvesting microalgae. The application of wastewater as a propagating medium offers a cost-effective approach in lowering the expense of deriving of microalgal-derived biodiesel, sustainable wastewater remediation, and sequestration of $\mathrm{CO}_{2}$ (Osundeko et al. 2019; Paddock et al. 2020).

It was stated that more than $70 \%$ of the fresh water in India is polluted making it unsuitable for human consumption (Dwivedi 2017). Effluents from industries, domestic waste, and agricultural lands discharged into water bodies contain elevated amount of heavy metals (zinc, cadmium, lead), nutrients like phosphate and nitrate, acids, and alkalis posing a serious threat to the ecosystem and the economy (Chekroun et al. 2014; Egede et al. 2016). Standard water treatment is an expensive process requiring a large amount of space and funding (Solovchenko et al. 2020). Nitrogen and phosphorus were repoted to be the main nutreints for algae which are abundant in wastewater (Sharma et al. 2020). Nitrogen exists as three species which are, ammonia, nitrate, and nitrite in wastewater which assimilated into amino acids to form proteins (Cai et al. 2013). Phosphorus exists as orthophosphate in wastewater which is 
utilized for the synthesis of phospholipids, adenosine triphosphates (ATP), and nucleic acids by the microalgae. Various reports have highlighted the feasibility of effluents from animal manure, municipality, brewery, and meat processing units as medium for propagation (Mulbry et al. 2005; Farooq et al. 2013; Lu et al. 2015; Otondo et al. 2018; Pham and Bui 2020). Microalgae can adapt to varying environmental conditions including nutrients, salinity, temperature, and UV radiation (Abdullah et al. 2019). They can be grown in different wastewater successfully lowered the chemical oxygen demand (COD), biological oxygen demand (BOD), nutrients like phosphorus and nitrogen which can be detrimental to aquatic life in high concentration (Abdel-Raouf et al. 2012). Coupling wastewater remediation and biodiesel production could lower microalgae biofuels. The estimated cost of producing microalgal oil from wastewater was $\$ 79.03$ barrel $^{-1}\left(\$ 1.88 \mathrm{gal}^{-1}\right)$ and the global price of oil vary between $\$ 26-107$ barrel $^{-1}$ indicating that cost of microalgal oil is at par and often lower (Pandey et al. 2020). Species of microalgae such as Chlorella vulgaris, C. sorokiniana, Scenedesmus obliquus, Botryococcus braunii, Phormidium bohneri are extensively used for wastewater treatment (Whitton et al. 2015; Nagi et al. 2020).

The objective of this study is to couple algal bioremediation of wastewater along with biodiesel production reducing the cost involved. In the present study, a novel microalgal strain, Pleusrastrum insigne isolated and grown in wastewater from different sources (agriculture, domestic, and tannery). The efficiency of this organism to remediate various parameters (odor, color, BOD, phosphorus, and nitrogen levels) of wastewater was analyzed. The growth and lipid productivity of the organism in different wastewaters was compared with the synthetic growth (Fogg's) medium. The lipid was extracted and profiled using GCMS. The fatty acids observed from lipid analysis were used to predict the biodiesel properties and were checked if they meet the Indian and International specifications

\section{Materials And Methods: \\ 2.1 Microalgal culture:}

Pleusrastrum insigne, with accession number MG940908, isolated from sewage in Mumbai, Maharashtra, India (used previously in the author's laboratory) was chosen for the study. The organism was maintained in Fogg's medium at pH 7.0, $25-26^{\circ} \mathrm{C}$ under natural sunlight (Fogg 1965; Ansari et al. 2017).

\subsection{Wastewater collection and characterization:}

Wastewater samples from sewage, agricultural fields, and tanneries from various locations were collected and their source, location, geographical coordinates, color, odor, and pH were noted (Alam et al. 2007). Safety measures for sample collection were followed. The collected effluents were carefully shifted to the laboratory, kept at $4^{\circ} \mathrm{C}$ (Pham and Bui 2020), characterized after $24 \mathrm{~h}$, and filtered (Whatman Grade 42 filter paper) to separate solid particles and unwanted debris (Chawla et al. 2020). BOD, total phosphorus (TP), and total nitrogen (TN) content of the samples were analyzed (APHA 2017). The concentration of orthophosphate $\left(\mathrm{PO}_{4}^{-3}\right)$ gave the TP and the TN was calculated by addition of known concentration of 
ammonia-nitrogen $\left(\mathrm{NH}_{3}-\mathrm{N}\right)$, nitrate-nitrogen $\left(\mathrm{NO}_{3}{ }^{-} \mathrm{N}\right)$, and nitrite-nitrogen $\left(\mathrm{NO}_{2}{ }^{-} \mathrm{N}\right)$ in the samples (Zabed et al. 2019).

\subsection{Cultivation of microalgae in wastewater and characterization:}

Two hundred milliliters of each wastewater were heated uunder pressure at $121^{\circ} \mathrm{C}, 15 \mathrm{psi}$ for 15 minutes to kill all the organisms present (Zhou et al. 2012). Thirty milliliters of broth culture of $P$. insigne $(\sim 0.06 \mathrm{~g}$ $\mathrm{ml}^{-1}$ ) was inoculated into each sample. Inoculated Fogg's medium was considered as control. Growth of $P$. insigne in the test and control samples were analyzed after every two days for 24 days using CL 157 Colorimeter at $\mathrm{I}_{670 \mathrm{~nm}}$ (Otondo et al. 2018). Wastewater was again characterized after culturing $P$. insigne to test its potential to remediate wastewater (Pham and Bui 2020).

\subsection{Estimation of dry cell weight and total lipid content:}

P. insigne propagated in wastewater and standard Fogg's medium were harvested, dried, and powdered after 14 days of incubation (end of log phase) and the total lipid extracted (Folch et al. 1957). The dry cell weight (dcw) and the total lipid content (\%) was calculated as per Pandey et al. 2019

Total lipid content $(\%)=$ Weight of the lipid $/$ dcw $\times 100(1)$

\subsection{Lipid Analysis:}

The extracted lipid was profiled using a Thermo Gas Chromatography (Trace Ultra Version 5.0) and (Thermo Mass Spectroscopy (DSQ II) as done by Singh et al. 2016. The column used for the study was DB 35 - MS capillary standard non - polar column with a dimension of $30 \mathrm{~m}, 0.25 \mathrm{~mm}$ ID, and $0.25 \mu \mathrm{m}$ film thickness. The temperature of the oven was started at $70^{\circ} \mathrm{C}$ for 2 mins and then progressively elevated to $260^{\circ} \mathrm{C}$ at a ramp rate of $6^{\circ} \mathrm{C} \mathrm{min}{ }^{-1}$. The carrier gas used was Helium at a $1.0 \mathrm{ml} \mathrm{min}{ }^{-1}$ constant flow rate with a split ratio of 30:1 (Singh et al. 2016)

\subsection{Analysis of FAME for biodiesel properties:}

Biodiesel properties can be calculated directly from the fatty acid profile generated from GCMS (Hoekman et al. 2012). In this study, an analytical software BiodieselAnalyzer Version 2.2 was employed to study the different properties of biodiesel (iodine value, kinematic viscosity at $25^{\circ} \mathrm{C}$, density, saponification number, oxidation stability, and cetane number) based on the fatty acid profile as per Talebi et al. 2014. These observed values were compared with standards given by the Indian Standards (IS), American Society for Testing and Materials (ASTM), and European Norms (EN).

\subsection{Statistical analyses:}

The estimations in this study were done in triplicates and statistical analyses were carried out with IBM SPSS Statistics 20 for Windows. The significant difference in the characteristics of wastewater, biomass production, and total lipid content were analsyed by One-way analysis of variance (ANOVA) and Duncan's Multiple Range Test (DMRT), $p$-value equal to or less than 0.05 was taken as a significant value. 


\section{Results And Discussion: \\ 3.1 Water samples}

Microalgae extensively thrive in wastewater suggesting that the nutrients and their concentration were suitable for growth (Whitton et al. 2015). In this study, wastewater was collected from different sources. The samples were obtained from the agricultural field (sample 1), sewage (sample 2), and tanneries. Tanneries produced different types of effluents based on the production and treatments which were raw soaked (sample 3), treated raw soaked (sample 4), lime bath (sample 5), dye bath (sample 6), treated lime and dye bath (sample 7), chrome (sample 8) and treated chrome (sample 9). The pH of all the water samples ranged between 6.8 - 9.8 except for chrome effluents (3.0) which was highly acidic. Table 1 shows the sources, locations, geographical coordinates, colors, odors, and pH of the different wastewater. The ability of each wastewater sample to promote microalgal growth was further studied.

Table 1

Wastewater samples collected from different sources

\begin{tabular}{|c|c|c|c|c|c|c|}
\hline Sample & Source & Location & $\begin{array}{l}\text { Geographical } \\
\text { coordinate }\end{array}$ & Color & Odor & $\mathrm{pH}$ \\
\hline 1 & $\begin{array}{l}\text { Agricultural } \\
\text { field }\end{array}$ & $\begin{array}{l}\text { Ramnagar, } \\
\text { Karnataka }\end{array}$ & $\begin{array}{l}12.7209^{\circ} \mathrm{N} \\
77.2799^{\circ} \mathrm{E}\end{array}$ & $\begin{array}{l}\text { Dark } \\
\text { green }\end{array}$ & $\begin{array}{l}\text { Slightly } \\
\text { pungent }\end{array}$ & 6.8 \\
\hline 2 & Sewage & $\begin{array}{l}\text { Bengaluru, } \\
\text { Karnataka }\end{array}$ & $\begin{array}{l}12.9352^{\circ} \mathrm{N}, \\
77.6244^{\circ} \mathrm{E}\end{array}$ & $\begin{array}{l}\text { Light } \\
\text { yellow }\end{array}$ & Pungent & 7.4 \\
\hline \multicolumn{7}{|c|}{ Tannery industry } \\
\hline 3 & Raw Soak & $\begin{array}{l}\text { Coimbatore, } \\
\text { Tamil Nadu }\end{array}$ & $\begin{array}{l}11.0168^{\circ} \mathrm{N} \\
76.9558^{\circ} \mathrm{E}\end{array}$ & $\begin{array}{l}\text { Light } \\
\text { yellow }\end{array}$ & $\begin{array}{l}\text { Strong } \\
\text { Pungent }\end{array}$ & 7.3 \\
\hline 4 & $\begin{array}{l}\text { Treated Raw } \\
\text { Soak }\end{array}$ & & & $\begin{array}{l}\text { Pale } \\
\text { yellow }\end{array}$ & Pungent & 9.0 \\
\hline 5 & Lime Bath & & & $\begin{array}{l}\text { Light } \\
\text { grey }\end{array}$ & Pungent & 9.8 \\
\hline 6 & Dye Bath & & & $\begin{array}{l}\text { Dark } \\
\text { grey }\end{array}$ & Pungent & 6.9 \\
\hline 7 & Treated Bath & & & Clear & Pungent & 6.6 \\
\hline 8 & Chrome & & & $\begin{array}{l}\text { Dark } \\
\text { blue }\end{array}$ & $\begin{array}{l}\text { Strong } \\
\text { Pungent }\end{array}$ & 3.0 \\
\hline 9 & $\begin{array}{l}\text { Treated } \\
\text { Chrome }\end{array}$ & & & Clear & Pungent & 7.2 \\
\hline
\end{tabular}

\subsection{Growth analysis}

Growth analysis (Fig. 1) showed that $P$. insigne exhibited a full growth phases (lag phase, log phase, and stationary phase) in samples $1,2,3,6$, and 7 similar to the control, where the exponential phase ends on 
the 14th day. But in samples $4,5,8$, and 9 , growth was observed only till the lag phase. The difference in the growth curve may be attributed to the amount of nutrients, $\mathrm{pH}$, and the occurrence of toxic compounds (Pittman et al. 2011; Jeong et al. 2020). TN : TP ratio higher than 16:1 is optimal for microalgal cultivation whereas pH less than 5 and pH higher than 8.0 is toxic (Azov and Shelef 1987; Monfet and Unc 2016). The samples where $P$. insigne exhibited a full growth cycle have TN:TP higher than 16:1. and a pH between 6.6 - 7.4. P. insigne cannot exhibit a full growth cycle in samples $8(\mathrm{pH} 3.0)$ and samples $4(\mathrm{pH} \mathrm{9.0)}$ and $5(\mathrm{pH} 9.8)$. Sample 9 has a neutral $\mathrm{pH}$ of 7.2 but cannot exhibit a full growth cycle as TN:TP is less than 16:1. It is however important to note that even if $P$. insigne cannot exhibit a full growth cycle in all the samples, the different parameters of the wastewater studied were significantly reduced in all the samples after it was treated with $P$. insigne.

\subsection{Characteristics of wastewater}

The BOD, TP and TN of each wastewater samples were analyzed before and after inoculation of $P$. insigne.

High level of BOD in the water reduced the amount of dissolved oxygen posing a threat to the aquatic life and therefore reduction of BOD is crucial for the remediation of wastewater (Abdel-Raouf et al. 2012). The BOD removal efficiency of $P$. insigne in different wastewater ranges from 54.84 to $93.61 \%$ as seen in Table 2 and Fig. 2. Our results were found to correlate with previous studies. A study has reported that the BOD removal efficiency of Chlorella vulgaris as $82.71 \%$ in sewage water from Gangneung sewage plant, Korea (Choi and Lee 2012). Another study showed that Chlorella sp. removed 59.1\% of the BOD from sewage wastewater at University of Nigeria (Henry et al. 2019). A recent research has shown that Chlorococcum sp. showed BOD removal efficiency of $83 \%$ in a river contaminated with pharmaceutical effluents (Singh et al. 2020). 
Table 2

Biological Oxygen Demand (BOD) of wastewater samples before and after cultivation of $P$. insigne with BOD removal efficiency of $P$. insigne

\begin{tabular}{|llll|}
\hline Samples & \multicolumn{3}{l}{ Biological Oxygen Demand (BOD) } \\
\cline { 2 - 4 } & $\begin{array}{l}\text { Before } \\
(\mathrm{mg} / \mathrm{L})\end{array}$ & $\begin{array}{l}\text { After } \\
(\mathrm{mg} / \mathrm{L})\end{array}$ & Removal efficiency (\%) \\
\hline 1 & $36 \pm 0.5$ & $2.3 \pm 0.04$ & 93.61 \\
\hline 2 & $21 \pm 0.3$ & $3.6 \pm 0.09$ & 82.86 \\
\hline 3 & $113 \pm 0.1$ & $36 \pm 0.1$ & 68.14 \\
\hline 4 & $10.4 \pm 0.4$ & $4.12 \pm 0.04$ & 60.38 \\
\hline 5 & $290 \pm 0.1$ & $116.9 \pm 0.2$ & 59.68 \\
\hline 6 & $310 \pm 0.2$ & $103 \pm 0.1$ & 66.77 \\
\hline 7 & $18.4 \pm 0.2$ & $1.2 \pm 0.02$ & 93.47 \\
\hline 8 & $220 \pm 0.1$ & $80 \pm 0.1$ & 63.63 \\
\hline 9 & $27.2 \pm 0.1$ & $12.84 \pm 0.2$ & 54.84 \\
\hline
\end{tabular}

A study on the TP removal efficiency of $P$. insigne in different wastewater samples indicated that the highest TP removal was observed in sample 3 (58.62\%) and sample 1 (54.54\%) as seen in Table 3 and Fig. 3. C. vulgaris successfully sequestrated $28 \%$ of the TP from industrial effluent (Valderrama et al. 2012) and another study observed that $C$. vulgaris removed $36.12 \%$ of the TP in sewage water from Gangneung sewage plant, Korea (Choi et al. 2012). It was estimated that Scenedesmus sp. and Chlorella sp. removed 70 and $80.5 \%$ respectively of the TP in untreated wastewater from the septic tank in Pakistan (Ansari et al. 2017). The TP removal efficiency of Tetraselmis indica in pharmaceutical wastewater was estimated as $70.03 \%$ (Amit et al. 2020). 
Table 3

Total phosphorus content of wastewater samples before and after cultivation of $P$. insigne with total phosphorus removal efficiency of $P$. insigne

\begin{tabular}{|llll|}
\hline Samples & \multicolumn{3}{l}{ Total Phosphorus (TP) } \\
\cline { 2 - 4 } & $\begin{array}{l}\text { Before } \\
(\mathrm{mg} / \mathrm{L})\end{array}$ & $\begin{array}{l}\text { After } \\
(\mathrm{mg} / \mathrm{L})\end{array}$ & Removal efficiency $(\%)$ \\
\hline 1 & $0.22 \pm 0.01$ & $0.10 \pm 0.02$ & $\mathbf{5 4 . 5 4}$ \\
\hline 2 & $0.13 \pm 0.02$ & $0.07 \pm 0.03$ & 46.15 \\
\hline 3 & $0.29 \pm 0.06$ & $0.12 \pm 0.03$ & $\mathbf{5 8 . 6 2}$ \\
\hline 4 & $0.23 \pm 0.02$ & $0.17 \pm 0.01$ & 26.08 \\
\hline 5 & $0.38 \pm 0.004$ & $0.30 \pm 0.02$ & 21.05 \\
\hline 6 & $0.49 \pm 0.03$ & $0.25 \pm 0.01$ & 48.97 \\
\hline 7 & $0.27 \pm 0.002$ & $0.15 \pm 0.001$ & 44.44 \\
\hline 8 & $1.74 \pm 0.004$ & $1.60 \pm 0.06$ & 12.28 \\
\hline 9 & $1.08 \pm 0.007$ & $1.00 \pm 0.01$ & 7.4 \\
\hline
\end{tabular}

The two highest TN reduction takes place in sample 1 (76.61\%) and sample 6 (73.06\%) as seen in Table 4 and Fig. 4. Previous study reported that Nitzschia sp. reduced the TN by $78 \%$ in municipal wastewater (Boelee et al. 2011) and an algal-bacterial coculture removed $70 \%$ of the TN in a treated domestic wastewater (Posadas et al. 2013). The TN removal efficiency of $C$. vulgaris in the dairy effluent was found to be $85.47 \%$ (Choi et al. 2016) Salgueiro et al. (2016) estimated that $C$. vulgaris removed $60-86 \%$ TN in a synthetic wastewater (Salgueiro et al. 2016) whereas Amit et al. (2020) showed $67.17 \%$ TN removal by Tetraselmis Indica in pharmaceutical wastewater. 
Table 4

Total concentration of ammonia-nitrogen, nitrate-nitrogen, nitrite-nitrogen and total nitrogen content of wastewater samples before and after cultivation of $P$. insigne with total nitorgen removal efficiency of $P$. insigne

\begin{tabular}{|c|c|c|c|c|c|c|c|c|c|}
\hline \multirow[t]{2}{*}{ Samples } & \multicolumn{2}{|c|}{$\begin{array}{l}\text { Concentration } \\
\text { of } \\
\text { ammonia- } \\
\text { nitrogen } \\
\text { (mg/L) }\end{array}$} & \multicolumn{2}{|c|}{$\begin{array}{l}\text { Concentration } \\
\text { of } \\
\text { nitrate-nitrogen } \\
(\mathrm{mg} / \mathrm{L})\end{array}$} & \multicolumn{2}{|c|}{$\begin{array}{l}\text { Concentration } \\
\text { of } \\
\text { nitrite-nitrogen } \\
(\mathrm{mg} / \mathrm{L})\end{array}$} & \multicolumn{3}{|c|}{ Total Nitrogen (TN) } \\
\hline & Before & After & Before & After & Before & After & $\begin{array}{l}\text { Before } \\
(\mathrm{mg} / \mathrm{L})\end{array}$ & $\begin{array}{l}\text { After } \\
(\mathrm{mg} / \mathrm{L})\end{array}$ & $\begin{array}{l}\text { Removal } \\
\text { efficiency } \\
(\%)\end{array}$ \\
\hline 1 & $\begin{array}{l}4.85 \pm \\
0.13\end{array}$ & $\begin{array}{l}0.87 \\
\pm \\
0.02\end{array}$ & $\begin{array}{l}0.11 \pm \\
0.03\end{array}$ & $\begin{array}{l}0.08 \pm \\
0.017\end{array}$ & $\begin{array}{l}1.38 \pm \\
0.12\end{array}$ & $\begin{array}{l}0.52 \pm \\
0.007\end{array}$ & $\begin{array}{l}6.351 \\
\pm 0.28\end{array}$ & $\begin{array}{l}1.485 \\
\pm \\
0.044\end{array}$ & 76.61 \\
\hline 2 & $\begin{array}{l}4.29 \pm \\
0.14\end{array}$ & $\begin{array}{l}1.08 \\
\pm \\
0.029\end{array}$ & $\begin{array}{l}0.09 \pm \\
0.025\end{array}$ & $\begin{array}{l}0.05 \pm \\
0.019\end{array}$ & $\begin{array}{l}0.94 \pm \\
0.08\end{array}$ & $\begin{array}{l}0.59 \pm \\
0.1\end{array}$ & $\begin{array}{l}5.331 \\
\pm \\
0.245\end{array}$ & $\begin{array}{l}1.733 \\
\pm \\
0.148\end{array}$ & 67.49 \\
\hline 3 & $\begin{array}{l}5.99 \pm \\
0.2\end{array}$ & $\begin{array}{l}2.11 \\
\pm \\
0.001\end{array}$ & $\begin{array}{l}0.10 \pm \\
0.003\end{array}$ & $\begin{array}{l}0.03 \pm \\
0.009\end{array}$ & $\begin{array}{l}1.34 \pm \\
0.02\end{array}$ & $\begin{array}{l}0.28 \pm \\
0.076\end{array}$ & $\begin{array}{l}7.446 \\
\pm \\
0.223\end{array}$ & $\begin{array}{l}2.434 \\
\pm 0.08\end{array}$ & 67.31 \\
\hline 4 & $\begin{array}{l}5.65 \pm \\
0.18\end{array}$ & $\begin{array}{l}2.79 \\
\pm \\
0.07\end{array}$ & $\begin{array}{l}0.23 \pm \\
0.03\end{array}$ & $\begin{array}{l}0.16 \pm \\
0.019\end{array}$ & $\begin{array}{l}0.62 \pm \\
0.027\end{array}$ & $\begin{array}{l}0.45 \pm \\
0.029\end{array}$ & $\begin{array}{l}6.511 \\
\pm \\
0.237\end{array}$ & $\begin{array}{l}3.419 \\
\pm \\
0.129\end{array}$ & 47.48 \\
\hline 5 & $\begin{array}{l}5.49 \pm \\
0.08\end{array}$ & $\begin{array}{l}3.84 \\
\pm \\
0.08\end{array}$ & $\begin{array}{l}0.06 \pm \\
0.003\end{array}$ & $\begin{array}{l}0.05 \pm \\
0.016\end{array}$ & $\begin{array}{l}0.53 \pm \\
0.012\end{array}$ & $\begin{array}{l}0.11 \pm \\
0.057\end{array}$ & $\begin{array}{l}6.097 \\
\pm \\
0.095\end{array}$ & $\begin{array}{l}4.017 \\
\pm \\
0.153\end{array}$ & 34.11 \\
\hline 6 & $\begin{array}{l}6.54 \pm \\
0.01\end{array}$ & $\begin{array}{l}1.42 \\
\pm \\
0.01\end{array}$ & $\begin{array}{l}0.17 \pm \\
0.005\end{array}$ & $\begin{array}{l}0.05 \pm \\
0.003\end{array}$ & $\begin{array}{l}1.51 \pm \\
0.001\end{array}$ & $\begin{array}{l}0.74 \pm \\
0.089\end{array}$ & $\begin{array}{l}8.231 \\
\pm \\
0.016\end{array}$ & $\begin{array}{l}2.217 \\
\pm \\
0.112\end{array}$ & 73.06 \\
\hline 7 & $\begin{array}{l}5.66 \pm \\
0.02\end{array}$ & $\begin{array}{l}3.45 \\
\pm \\
0.07\end{array}$ & $\begin{array}{l}0.05 \pm \\
0.003\end{array}$ & $\begin{array}{l}0.03 \pm \\
0.004\end{array}$ & $\begin{array}{l}2.09 \pm \\
0.003\end{array}$ & $\begin{array}{l}0.42 \pm \\
0.024\end{array}$ & $\begin{array}{l}7.808 \\
\pm \\
0.026\end{array}$ & $\begin{array}{l}3.925 \\
\pm \\
0.098\end{array}$ & 49.73 \\
\hline 8 & $\begin{array}{l}3.84 \pm \\
0.03\end{array}$ & $\begin{array}{l}3.16 \\
\pm \\
0.05\end{array}$ & $\begin{array}{l}0.44 \pm \\
0.023\end{array}$ & $\begin{array}{l}0.43 \pm \\
0.059\end{array}$ & $\begin{array}{l}2.44 \pm \\
0.042\end{array}$ & $\begin{array}{l}0.57 \pm \\
0.018\end{array}$ & $\begin{array}{l}6.735 \\
\pm \\
0.095\end{array}$ & $\begin{array}{l}4.168 \\
\pm \\
0.127\end{array}$ & 38.11 \\
\hline 9 & $\begin{array}{l}4.48 \pm \\
0.01\end{array}$ & $\begin{array}{l}3.21 \\
\pm \\
0.05\end{array}$ & $\begin{array}{l}0.11 \pm \\
0.056\end{array}$ & $\begin{array}{l}0.065 \\
\pm \\
0.012\end{array}$ & $\begin{array}{l}0.367 \\
\pm \\
0.003\end{array}$ & $\begin{array}{l}0.336 \\
\pm \\
0.017\end{array}$ & $\begin{array}{l}4.964 \\
\pm \\
0.083\end{array}$ & $\begin{array}{l}3.612 \\
\pm \\
0.079\end{array}$ & 27.2 \\
\hline
\end{tabular}

\subsection{Biomass and lipid production}

P. insigne grown in Fogg's medium(control) and in samples which promote a full growth cycle (samples 1 , $2,3,6$ and 7) were harvested, dried and powdered. The dcw and total lipid content of $P$. insigne differed in different samples (Fig. 5). The dcw of the organism was highest in control $\left(1.67 \mathrm{~g} \mathrm{~L}^{-1}\right)$ followed by 
samples 2 and 1 (1.22 and $1.11 \mathrm{~g} \mathrm{~L}^{-1}$ respectively). Mahapatra et al. (2014) reported the biomass obtained from a microalgal consortium culture in municipal effluents was found to be $1.64 \mathrm{~g} \mathrm{~L}^{-1}$. A study done has shown that pure cultures of $C$. saccharophila, Scenedesmus sp. and a consortium culture can be successfully grown in treated and raw dairy wastewater with higher dcw of $0.276 \mathrm{~g} \mathrm{~L}^{-1}$ obtained from a consortium culture in a treated dairy wastewater (Hena et al.2015). Nguyen et al. (2019) cultivated $C$. vulgaris in seafood processing wastewater effluent and harvested $0.46 \mathrm{~g} \mathrm{~L}^{-1}$.

The total lipid accumulation was higher in all the samples compared to control. $P$. insigne grown in samples 3 and 6 which produced the highest lipid, $30.1 \%$ and $30.47 \%$ respectively. The total lipid content in this study were found to be in par with the lipid yielded by various microalgae in different media used for biodiesel production. C. pyrenoidosa grown in palm oil mill effluent (POME) produced $42 \%$ lipid (Ponraj and Din 2013). Lipid yield of $28 \%$ dry cell weight was obtained from Chlorococcum sp. cultivated in pharmaceutical effluents (Sing et al. 2020). A closer analysis has shown that biomass production in inversely proportional to lipid production. The composition of the growth medium greatly influenced the biomass and lipid production (Lam and Lee 2012). Biotic and abiotic stress may lead to decreased in growth but produce higher lipid (Karpagam et al. 2015). A standard Fogg's medium has the most suitable concentration of various nutrients and $\mathrm{pH}$ for the growth of microalgae. The highest TN:TP ratio was found in sample 2 followed by sample 1. Hence $P$. insigne grown in Fogg's medium and samples 1 and 2 produced high biomass but lesser lipid. The TN:TP ratio is low in samples 3 and 6 compare to other samples 1,2 and 7 , therefore $P$. insigne produced less biomass but higher lipid in these samples. The lipids produced can be further transesterified for the production of biodiesel.

\subsection{Fatty acid profile and characterization of biodiesel:}

Lipid was extracted from $P$. insigne grown in sample 6 since lipid yield was highest. GCMS has revealed that varied types of fatty acids (Table 5) were present in the extracted lipid as similar to earlier study (Miranda et al. 2016). A study on the fatty acid profile has shown the presence of large concentration of C16 and C18 fatty acids which are desirable fatty acids for a high grade fuel (Selvarajan et al. 2015). The detection of palmitic acid also proved to be a great significance for the study as it is an important pointer for assessing the quality of biodiesel derived from microalgae (Demirbas 2008). The observed values for the different fuel properties tested were given in Table 6. A low iodine value is preferred because a high iodine value promotes polymerization of glycerides which can hinder the performance of an engine. The minimum cetane number for a fuel is 47 because high cetane number indicates a greater ease of ignition and lesser emission of nitrous oxide $\left(\mathrm{N}_{2} \mathrm{O}\right)$ (Selvarajan et al. 2015). High viscous fuel may result in poor fuel combustion and therefore the kinematic viscosity should be within an acceptable range (Phankosol and Krisnangkura 2015). The density should be within a specific limit for ideal air-to-fuel ratios for complete combustion (Ismail and Ali 2015). Saponification number signify the purity of the fuel (Mohan et al. 2019) and oxidative stability relates to the resistance of the fuel to oxidation, which also depends on time (age of the biodiesel) and storage condition (Hoekman et al. 2012). All the observed values of the fuel properties were within the standards of IS (1448), ASTM (D6751-08) and Europe (EN 14214) which confirm that biodiesel produced from $P$. insigne cultivated in wastewater is of high quality. 
Table 5

GCMS showing different type of fatty acids extracted from P. insigne grown in Sample 6

\begin{tabular}{|lllll|}
\hline SI. No. & Fatty Acids & Retention Time (RT) & Molecular weight & Percentage (\%) \\
\hline 1 & Myristic acid (C14:0) & 10.45 & 228.37 & 3.63 \\
\hline 2 & Pentadecanoic acid (C15:0) & 12.23 & 242.40 & 30.90 \\
\hline 3 & Palmitic acid (C16:0) & 12.65 & 256.42 & 34.54 \\
\hline 4 & Oleic acid (C18:1) & 15.25 & 564.90 & 24.72 \\
\hline 5 & Stearic acid (C18:0) & 15.57 & 284.50 & 2.54 \\
\hline 6 & Linoleic acid (C18:2) & 18.92 & 280.40 & 3.63 \\
\hline
\end{tabular}

Table 6

The observed values of different properties of biodiesel obtained from P.insigne with international standards

\begin{tabular}{|c|c|c|c|c|}
\hline \multirow[t]{2}{*}{ Properties } & \multirow[t]{2}{*}{$\begin{array}{l}\text { Observed } \\
\text { value }\end{array}$} & $\begin{array}{l}\text { IS } \\
\text { (1448) }\end{array}$ & $\begin{array}{l}\text { ASTM (D6751- } \\
\text { 08) }\end{array}$ & $\begin{array}{l}\text { Europe (EN } \\
14214)\end{array}$ \\
\hline & & Limit & Limit & Limit \\
\hline lodine value $\left(\mathrm{gl}_{2} 100 \mathrm{~g}^{-1} \mathrm{fat}\right)$ & 8.85 & $\leq 120$ & NA & $\leq 120$ \\
\hline Cetane Number & 69.49 & $\geq 47$ & $\geq 47$ & $\geq 47$ \\
\hline $\begin{array}{l}\text { Kinematic viscosity at } 25^{\circ} \mathrm{C} \\
\left(\mathrm{mm}^{2} / \mathrm{s}\right)\end{array}$ & 3.84 & $3.5-5.0$ & $1.9-6.0$ & $3.5-5.0$ \\
\hline Density $\left(\mathrm{kg} / \mathrm{m}^{3}\right)$ & 866 & $\begin{array}{l}860- \\
900\end{array}$ & NA & $860-900$ \\
\hline $\begin{array}{l}\text { Saponification number (mg } \\
\mathrm{KOHg}^{-1} \text { ) }\end{array}$ & 216 & NA & NA & NA \\
\hline Oxidation Stability (h) & 35.08 & $\geq 8.0$ & $\geq 3.0$ & $\geq 6.0$ \\
\hline
\end{tabular}

\section{Conclusion:}

The deteriorating effect of improper disposal of waste into waster bodies and overexploitation of fossil fuels leads to loss of aquatic species and climate change. The development of an alternative form of energy source which is sustainable, economically feasible and eco-friendly is the need of the hour. When $P$. insigne was grown in different wastewater samples it decreased the concentration of the organic pollutants while the wastewater served as a culture media for the organism. The lipid content and fatty acid analysis of $P$. insigne grown in wastewater was shown to be in par with other microalgae studied for biodiesel production. Therefore this study successfully demonstrated the scope of using microalgae as a feedstock for biodiesel production while mitigating the concentration of harmful pollutant in the wastewater bodies. 


\section{Declarations}

\section{Acknowledgement:}

The authors would like to acknowledge Biotechnology Department, School of Sciences, JAIN (deemed-tobe University), Bangalore, Karnataka, India for providing laboratory and intellectual assistance to carry out this study. There are no grants and funds received from any agencies.

\section{Competing interest:}

The authors approved that there is no conflicts of interest and that the manuscript is not being considered by any other journals for publication.

Ethical Approval: Not Applicable

Consent to Participate: Not Applicable

\section{Authors Contribution:}

The authors confirm contribution to the paper as follows: study conception and design: Michael Van Lal Chhandama; data collection: Michael Van Lal Chhandama; analysis and interpretation of results: Michael Van Lal Chhandama, Kumudini Belur Satyan; draft manuscript preparation: Michael Van Lal Chhandama, Kumudini Belur Satyan. Both the authors reviewed the results and approved the final version of the manuscript

Funding: Not Applicable

Availability of Data: Not Applicable

Consent to Publish: Not Applicable

\section{References}

1. Abdel-Raouf N, Al-Homaidan AA, Ibraheem IBM (2012) Microalgae and wastewater treatment. Saudi J Biol Sci 19(3):257-275. https://doi.org/10.1016/j.sjbs.2012.04.005

2. Abdullah B, Muhammad SAFS, Shokravi Z, Ismail S, Kasim KA, Mahmood AN, Aziz MMA (2019) Fourth generation biofuel: A review on risks and mitigation strategies. Renew Sust Energ Rev 107:37-50. https://doi.org/10.1016/j.rser.2019.02.018

3. Alam ASMM, Hossain KM, Hossain B, Ahmed A, Hoque MJ (2007) A study on industrial waste effluents and their management at selected food and beverage industries of Bangladesh. J Appl Sci Environ Manage 11(4):5-9

4. Amit JK, Nayak UK, Ghosh (2020) Microalgal remediation of anaerobic pretreated pharmaceutical wastewater for sustainable biodiesel production and electricity generation. J Water Process Eng 
35:101192. https://doi.org/10.1016/j.jwpe.2020.101192

5. Ananthi V, Raja R, Carvalho IS, Brindhadevi K, Pugazhendhi A, Arun A (2021) A realistic scenario on microalgae based biodiesel production: Third generation biofuel. Fuel 284:118965. https://doi.org/10.1016/j.fuel.2020.118965

6. Ansari AA, Khoja AH, Nawar A, Qayyum M, Ali E (2017) Wastewater treatment by local microalgae strains for $\mathrm{CO}_{2}$ sequestration and biofuel production. Appl Water Sci 7:4151-4158. https://doi.org/10.1007/s13201-017-0574-9

7. APHA (American Public Health Association) (2017) Standard Methods for the examination of Water and Wastewater, 23rd edn. American Public Health Association/American water works Association/Water environment Federation, Washington, DC

8. Azov Y, Shelef $\mathrm{G}$ (1987) The effect of $\mathrm{pH}$ on the performance of the high-rate oxidation ponds. Water Sci Technol 19(12):381-383. https://doi.org/10.2166/wst.1987.0177

9. Boelee NC, Temmink H, Janssen M, Buisman CJN, Wijffels RH (2011) Nitrogen and phosphorus removal from municipal wastewater effluent using microalgal biofilms. Water Res 45(18):59255933. https://doi.org/10.1016/j.watres.2011.08.044

10. Cai T, Park SY, Li Y (2013) Nutrient recovery from wastewater streams by microalgae: status and prospects. Renew Sust Energ Rev 19:360-369. https://doi.org/10.1016/j.rser.2012.11.030

11. Chawla P, Malik A, Sreekrishnan TR (2020) Selection of optimum combination via comprehensive comparison of multiple algal cultures for treatment of diverse wastewaters. Environ Technol Inno 18:100758. https://doi.org/10.1016/j.eti.2020.100758

12. Chekroun KB, Sánchez E, Baghour M (2014) The role of algae in bioremediation of organic pollutants. Int Res J Public Environ Health 1:19-32

13. Choi HJ, Lee SM (2012) Effects of Microalgae on the Removal of Nutrients from Wastewater: Various Concentrations of Chlorella vulgaris. Environ Eng Res 17:3-8. http://dx.doi.org/10.4491/eer.2012.17.S1.S3

14. Choi HJ (2016) Dairy wastewater treatment using microalgae for potential biodiesel application. Environ Eng Res 21:393-400. https://doi.org/10.4491/eer.2015.151

15. David M (2018) The role of organized publics in articulating the exnovation of fossil-fuel technologies for intra-and intergenerational energy justice in energy transitions. Appl Energy 228:339-350. https://doi.org/10.1016/j.apenergy.2018.06.080

16. Demirbas A (2008) Studies on cottonseed oil biodiesel prepared in non-catalytic SCF conditions. Bioresour Technol 99(5):1125-1130. https://doi.org/10.1016/j.biortech.2007.02.024

17. Dwivedi AK (2017) Researches in water pollution: a review. Int Res Jour Nat Appl Sci 118-142. http://dx.doi.org/10.13140/RG.2.2.12094.08002

18. Egede EJ, Jones H, Cook B, Purchase D, Mouradov A (2016) Application of microalgae and fungalmicroalgal associations for wastewater treatment.. In: In: Purchase D (ed) Fungal applications in sustainable environmental biotechnology. Springer International Publishing, Germany, pp 143-181 
19. Farooq W, Lee YC, Ryu BG, Kim BH, Kim HS, Choi YE, Yang JW (2013) Two-stage cultivation of two Chlorella sp. strains by simultaneous treatment of brewery wastewater and maximizing lipid productivity. Bioresour Technol 113:230-238. https://doi.org/10.1016/j.biortech.2013.01.034

20. Fogg GE (1965) Algal culture and phytoplankton ecology. University Wisconsin Press, Madison

21. Folch J, Lees M, Stanley GHS (1957) A simple method for the isolation and purification of total lipids from animal tissues. J Biol Chem. 226: 497-509. PMID: 13428781

22. Hena S, Fatimah S, Tabassum S (2015) Cultivation of algae consortium in a dairy farm wastewater for biodiesel production. Water Resour Ind 10:1-14. https://doi.org/10.1016/j.wri.2015.02.002

23. Henry AO, Rejoice Al, Cornelius EC, AdenikeKafilat K, Iworah CO, Nkechi OM et al (2019) Determination of uptake rate of phosphorus and changes in COD and BOD during photoautotrophic cultivation of microalgae in sewage effluent. WJARR 1-9. http://dx.doi.org/10.30574/wjarr.2019.4.2.0083

24. Hoekman SK, Broch A, Robbins C, Ceniceros E, Natarajan M (2012) Review of biodiesel composition, properties, and specifications. Renew Sust Energ Rev 16(1):143-169. https://doi.org/10.1016/j.rser.2011.07.143

25. Hossain ABMS, Salleh A, Nasrulhaq AB, Chowdhury P, Naqiuddin M (2008) Biodiesel fuel production from algae as renewable energy. Am J Biochem Biotechnol 250-254. http://dx.doi.org/10.3844/ajbbsp.2008.250.254

26. Ismail SAA, Ali RFM (2015) Physico-chemical properties of biodiesel manufactured from waste frying oil using domestic adsorbents. Sci Technol Adv Mater 16(3):1-9. http://dx.doi.org/10.1088/1468-6996/16/3/034602

27. Jeong D, Jang A (2020) Exploration of microalgal species for simultaneous wastewater treatment and biofuel production. Environ Res 109772. https://doi.org/10.1016/j.envres.2020.109772

28. Karpagam R, Raj KJ, Ashokkumar B, Varalakshmi P (2015) Characterization and fatty acid profiling in two fresh water microalgae for biodiesel production: Lipid enhancement methods and media optimization using response surface methodology. Bioresour Technol 118:177-184. https://doi.org/10.1016/j.biortech.2015.01.053

29. Lam MK, Lee KT (2021) Potential of using organic fertilizer to cultivate Chlorella vulgaris for biodiesel production. Appl Energy 94:303-308. https://doi.org/10.1016/j.apenergy.2012.01.075

30. Lu Q, Zhou W, Min M, Ma X, Chandra C, Doan YT et al (2015) Growing Chlorella sp. on meat processing wastewater for nutrient removal and biomass production. Bioresour Technol 198:189197. https://doi.org/10.1016/j.biortech.2015.08.133

31. Mahapatra DM, Hoysall C, Ramachandra TV (2014) Bioremediation and lipid synthesis through mixotrophic algal consortia in municipal wastewater. Bioresour Technol 168:142-150. https://doi.org/10.1016/j.biortech.2014.03.130

32. Miranda CT, de Lima DVN, Atella GC, de Aguiar PF, Azevedo SMFO (2016) Optimization of nitrogen, phosphorus and salt for lipid accumulation of microalgae: towards the viability of microalgae biodiesel. Nat Sci 8:557-573. http://dx.doi.org/10.4236/ns.2016.812055 
33. Mohan SV, Rohit MV, Subash GV, Chandra R, Devi MP, Butti SK, Rajesh K (2019) Algal oils as biodiesel, In: Pandey A, Chang JS, Soccol CR, Lee DJ, Chisti Y, editors. Biomass, biofuels and biochemicals: biofuels from algae, second edition. Elsevier. p. 287-323

34. Monfet E, Unc A (2016) Defining wastewaters used for cultivation of algae. Algal Res 24:520-526. http://dx.doi.org/10.1016/j.algal.2016.12.008

35. Mulbry W, Westhead EK, Pizarro C, Sikora L (2005) Recycling of manure nutrients: use of algal biomass from dairy manure treatment as a slow release fertilizer. Bioresour Technol 96(4):451-458. http://dx.doi.org/10.1016/j.biortech.2004.05.026

36. Murthy GP, Kumar R (2019) Optimized production of biodiesel by fresh water algae oils derived from Chlorella wild stuff and performance characteristics of engine system by employing integration of chemical sciences and engineering technologies. Int J Chem Technol 26(5):381-395

37. Nagi M, He M, Li D, Gebreluel T, Cheng B, Wang C (2020) Utilization of tannery wastewater for biofuel production: New insights on microalgae growth and biomass production. Sci Rep 1530. https://doi.org/10.1038/s41598-019-57120-4

38. Nguyen TDP, Tran TNT, Le TVA, Phan TXN, Show PL, Chia SR (2019) Auto-flocculation through cultivation of Chlorella vulgaris in seafood wastewater discharge: Influence of culture conditions on microalgae growth and nutrient removal. Bioscien Bioengi 127(4):492-498. https://doi.org/10.1016/j.jbiosc.2018.09.004

39. Osundeko O, Ansolia P, Gupta SK, Bag P, Bajhaiya AK (2019) Promises and challenges of growing microalgae in wastewater.. In: In: Singh RP, Kolok AS, Bartelt-Hunt SL (eds) Water conservation, recycling and reuse: issues and challenges. Springer, Singapore, pp 29-53

40. Otondo A, Kokabian B, Stuart-Dahl S, Gude VG (2018) Energetic evaluation of wastewater treatment using microalgae, Chlorella vulgaris. J Environ Chem Eng 6(2):3213-3222. https://doi.org/10.1016/j.jece.2018.04.064

41. Paddock MB, Fernández-Bayo JD, VanderGheynst JS (2020) The effect of the microalgae-bacteria microbiome on wastewater treatment and biomass production. Appl Microbiol Biotechnol 104(2):893-905. https://doi.org/10.1007/s00253-019-10246-x

42. Padmanabhan A, Stanley SA (2012) Microalgae as an Oil Producer for Biofuel Applications.Res J Recent Sci.57-62

43. Pandey A, Srivastava S, Kumar S (2020) Development and cost-benefit analysis of a novel process for biofuel production from microalgae using pre-treated high-strength fresh cheese whey wastewater. Environ Sci Pollut Res 27:23963-23980. https://doi.org/10.1007/s11356-020-08535-4

44. Pandey MK, Dasgupta CN, Mishra S, Srivastava M, Gupta VK, Suseela MR, Ramteke PW (2019) Bioprospecting microalgae from natural algal bloom for sustainable biomass and biodiesel production. Appl Microbiol Biotechnol 103:5447-5458. https://doi.org/10.1007/s00253-019-09856-2

45. Pham TL, Bui MH (2020) Removal of nutrients from fertilizer plant wastewater using Scenedesmus sp.: formation of bioflocculation and enhancement of removal efficiency. J Chem 1-9. https://doi.org/10.1155/2020/8094272 
46. Phankosol S, Krisnangkura K (2015) Estimation kinematic viscosity of biodiesel produced by ethanolysis.Eng Trans.103-106

47. Pittman JK, Dean AP, Osundeko O (2011) The potential of sustainable algal biofuel production using wastewater resources. Bioresour Technol 102(1):17-25.

https://doi.org/10.1016/j.biortech.2010.06.035

48. Ponraj M, Din MFM (2013) Effect of light/dark cycle on biomass and lipid productivity by Chlorella pyrenoidosa using palm oil mill effluent (POME). J Sci Ind Res 72(11):703-706

49. Posadas E, García-Encina PA, Soltau A, Domínguez A, Díaz I, Munoz R (2013) Carbon and nutrient removal from centrates and domestic wastewater using algal-bacterial biofilm bioreactors.

Bioresour Technol 139:50-58. https://doi.org/10.1016/j.biortech.2013.04.008

50. Salgueiro JL, Perez L, Maceiras R, Sanchez A, Cancela A (2016) Bioremediation of wastewater using Chlorella vulgaris microalgae: phosphorus and organic matter. Int J Environ Res 465-470. https://dx.doi.org/10.22059/ijer.2016.58766

51. Selvarajan R, Felföldi T, Tauber T, Sanniyasi E, Sibanda T, Tekere M (2015) Screening and evaluation of some green algal strains (Chlorophyceae) isolated from freshwater and soda lakes for biofuel production. Energies 8:7502-7521. http://dx.doi.org/10.3390/en8077502

52. Sharma J, Kumar V, Kumar SS (2020) Microalgal consortia for municipal wastewater treatment Lipid augmentation and fatty acid profiling for biodiesel production. J Photochem Photobiol B. 111638- 111248. https://doi.org/10.1016/j.jphotobiol.2019.111638. PMID: 31733613

53. Singh A, Ummalyma SB, Sahoo D (2020) Bioremediation and biomass production of microalgae cultivation in river water contaminated with pharmaceutical effluent. Bioresour Technol 123233. https://doi.org/10.1016/j.biortech.2020.123233

54. Singh P, Guldhe A, Kumari S, Rawat I, Bux F (2016) Combined metals and EDTA control: An integrated and scalable lipid enhancement strategy to alleviate biomass constraints in microalgae under nitrogen limited conditions. Energy Convers Manag.100-109

55. Solovchenko A, Lukyanov GA, Aswathanarayana RG, Pleisser D, Ambati RR, Ravishankar (2020) Recent developments in microalgal conversion of organics-enriched waste streams. Curr Opim Green Sust Chem 24:61-66. https://doi.org/10.1016/j.cogsc.2020.03.006

56. Talebi AF, Tabatabaei M, Chisti Y (2014) BiodieselAnalyzer: a user-friendly software for predicting the properties of prospective biodiesel. Biofuel Res J 55-57. https://dx.doi.org/10.18331/BRJ2015.1.2.4

57. Tariyal K, Bartwal DM, Bartwal S (2013) Algal biofuel: A symbol of sustainability in the developmental era.Sch Acad J Biosci.192-197

58. United Nations Environment Programme (UNEP) (2020) World's governments must wind down fossil fuel production by $6 \%$ per year to limit catastrophic warming. [accessed 20 March 2021]. https://www.unep.org/news-and-stories/press-release

59. Valderrama LT, Del Campo CM, Rodriguez CM, de Bashan LE, Bashan Y (2002) Treatment of recalcitrant wastewater from ethanol and citric acid production using the microalga Chlorella 
vulgaris and the macrophyte Lemna minuscula. Water Res 36(17):4185-4192.

https://doi.org/10.1016/s0043-1354(02)00143-4

60. Whitton R, Ometto F, Pidou M, Jarvis P, Villa R, Jefferson B (2015) Microalgae for municipal wastewater nutrient remediation: mechanisms, reactors and outlook for tertiary treatment. Environ Technol Rev 133-148. https://doi.org/10.1080/21622515.2015.1105308

61. Yadav M, Chavan SB, Singh R, Bux F, Sharma YC (2019) Experimental study on emissions of algal biodiesel and its blends on a diesel engine. J Taiwan Inst Chem Eng 160-168.

http://dx.doi.org/10.1016/j.jtice.2018.10.022

62. Zabed HM, Akter S, Yun J, Zhang G, Awad FN, Qi X, Sahu JN (2019) Recent advances in biological pretreatment of microalgae and lignocellulosic biomass for biofuel production. Renew Sust Energ Rev 105:105-128. https://doi.org/10.1016/j.rser.2019.01.048

63. Zhou W, Min M, Hu B, Ma X, Cheng Y, Chen P (2012) A heterophotoautotrophic two-stage cultivation process to improve wastewater nutrient removal and enhance algal lipid accumulation. Bioresour Technol 110:448-455. https://doi.org/10.1016/j.biortech.2012.01.063

\section{Figures}

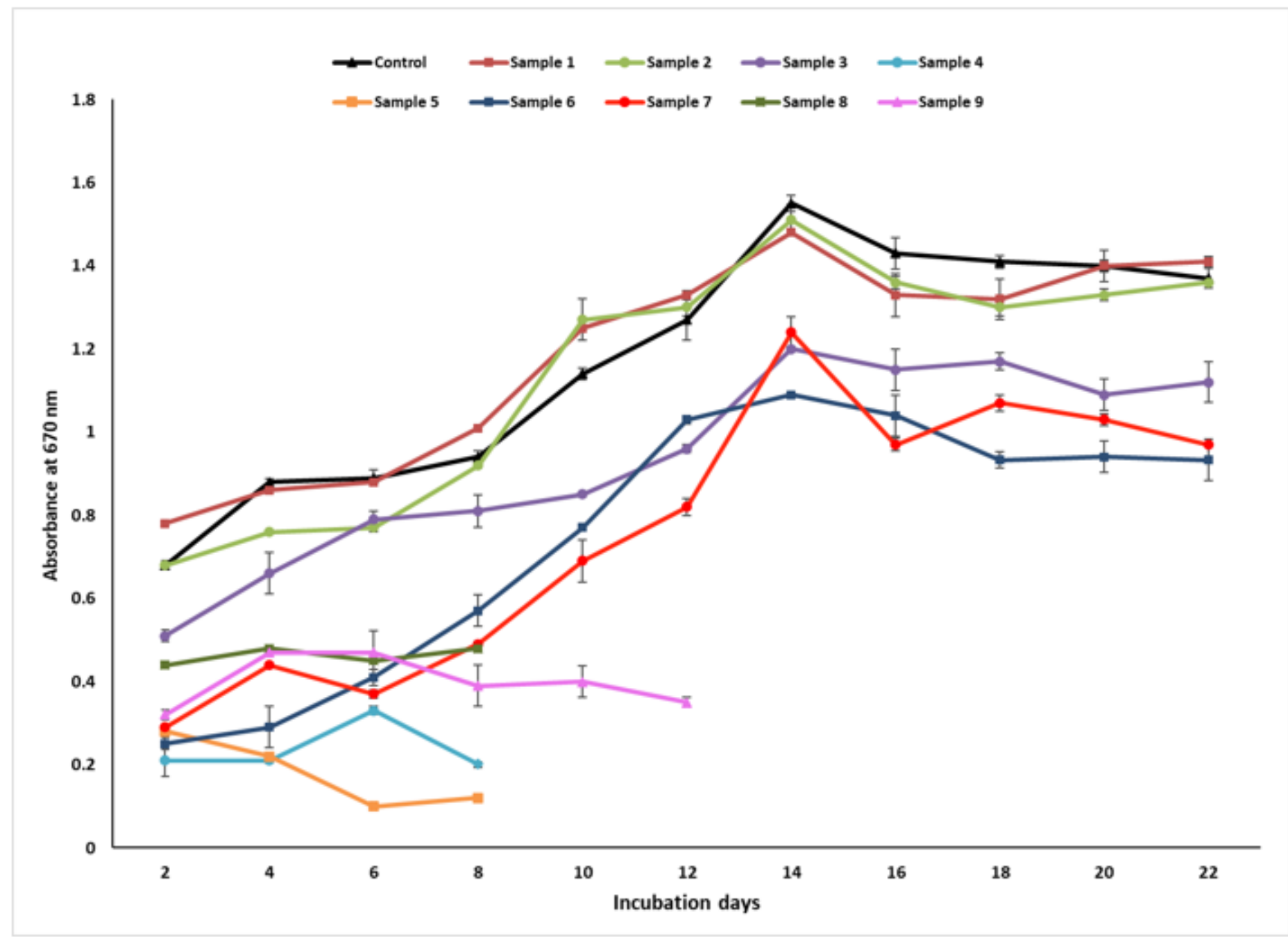


Figure 1

Growth curve of $P$. insigne cultivated in various wastewater samples

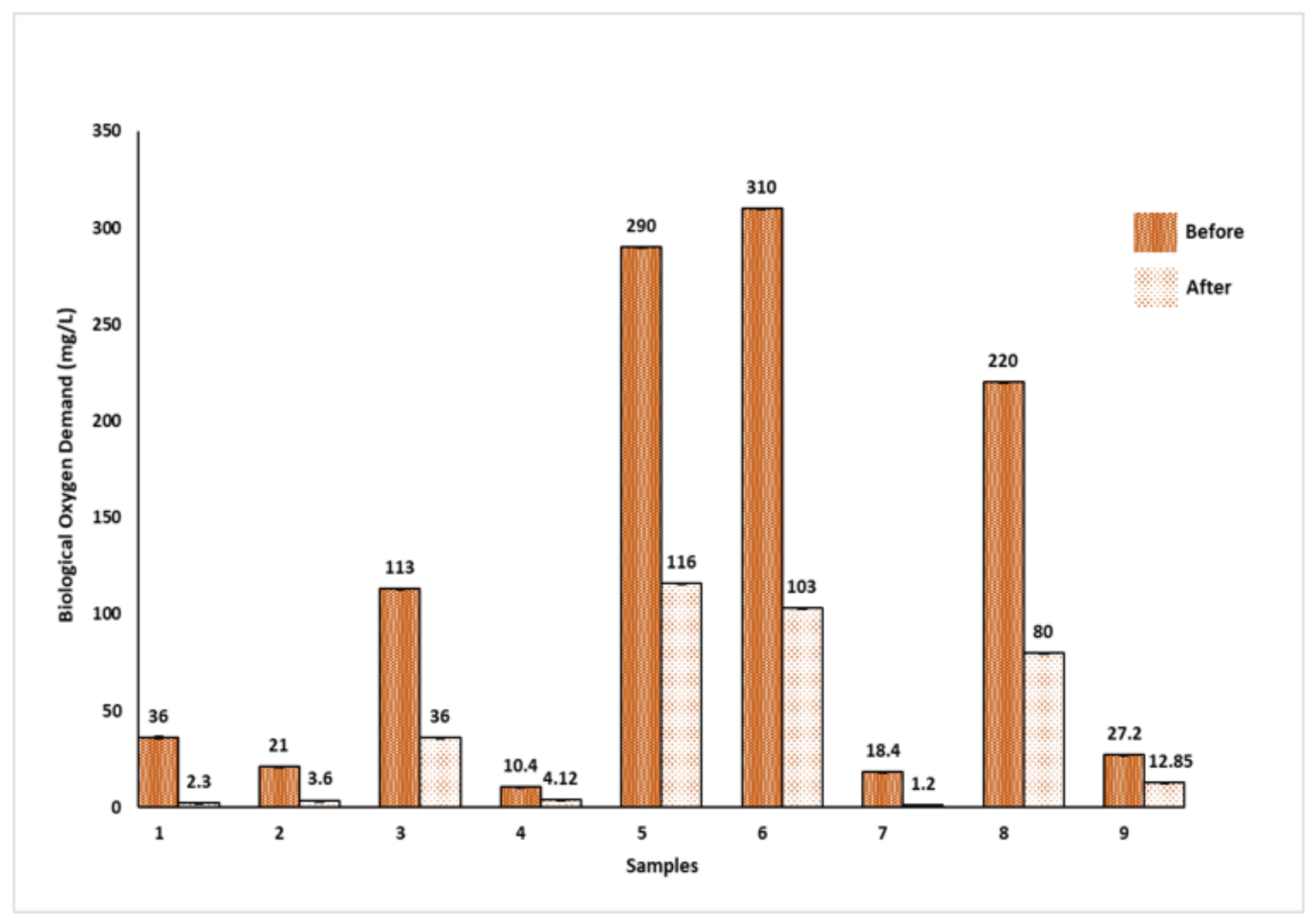

Figure 2

Biological Oxygen Demand (BOD) of wastewater samples before and after cultivation of $P$. insigne 


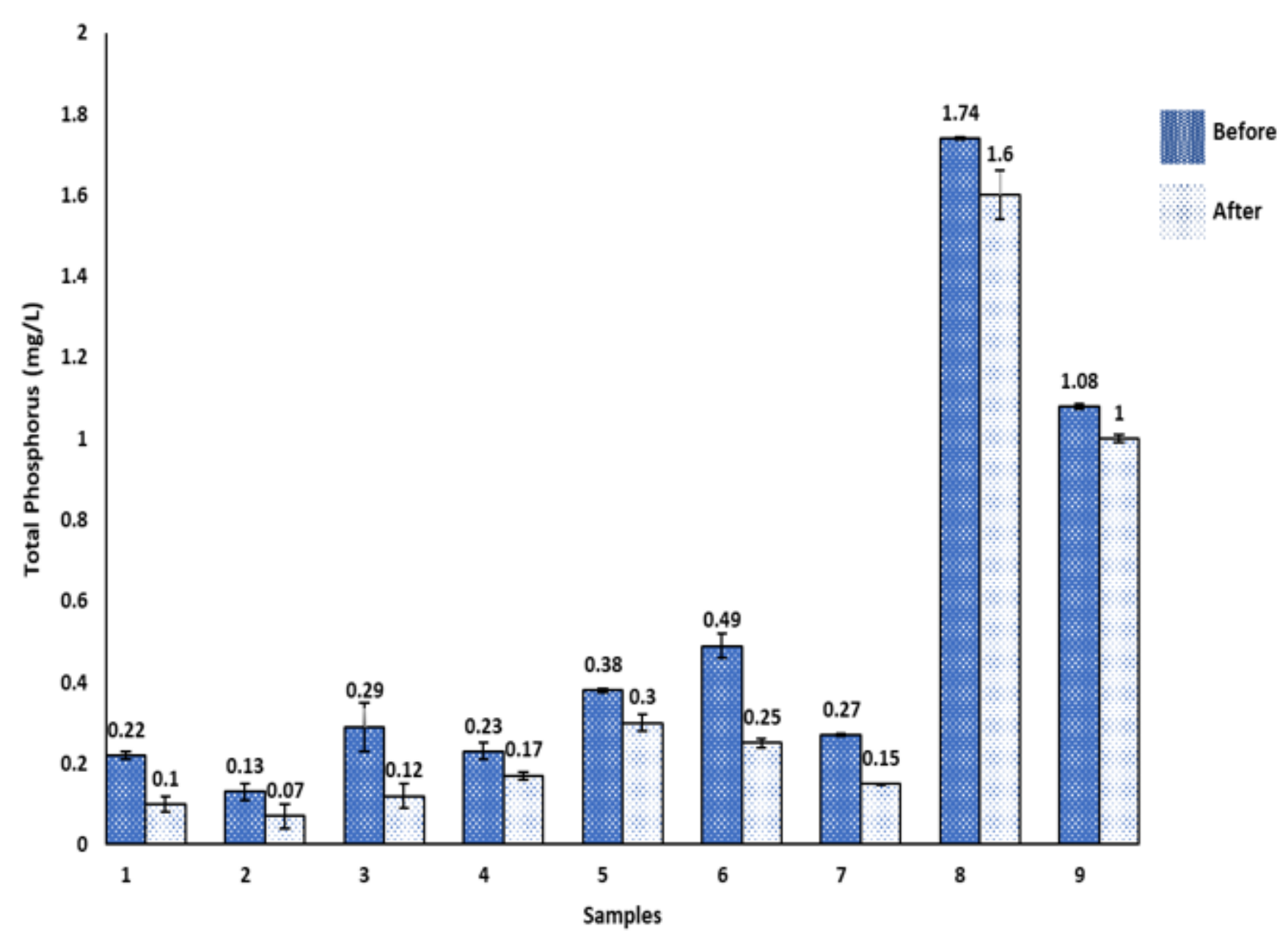

Figure 3

Total phosphorus content of wastewater samples before and after cultivation of $P$. insigne 


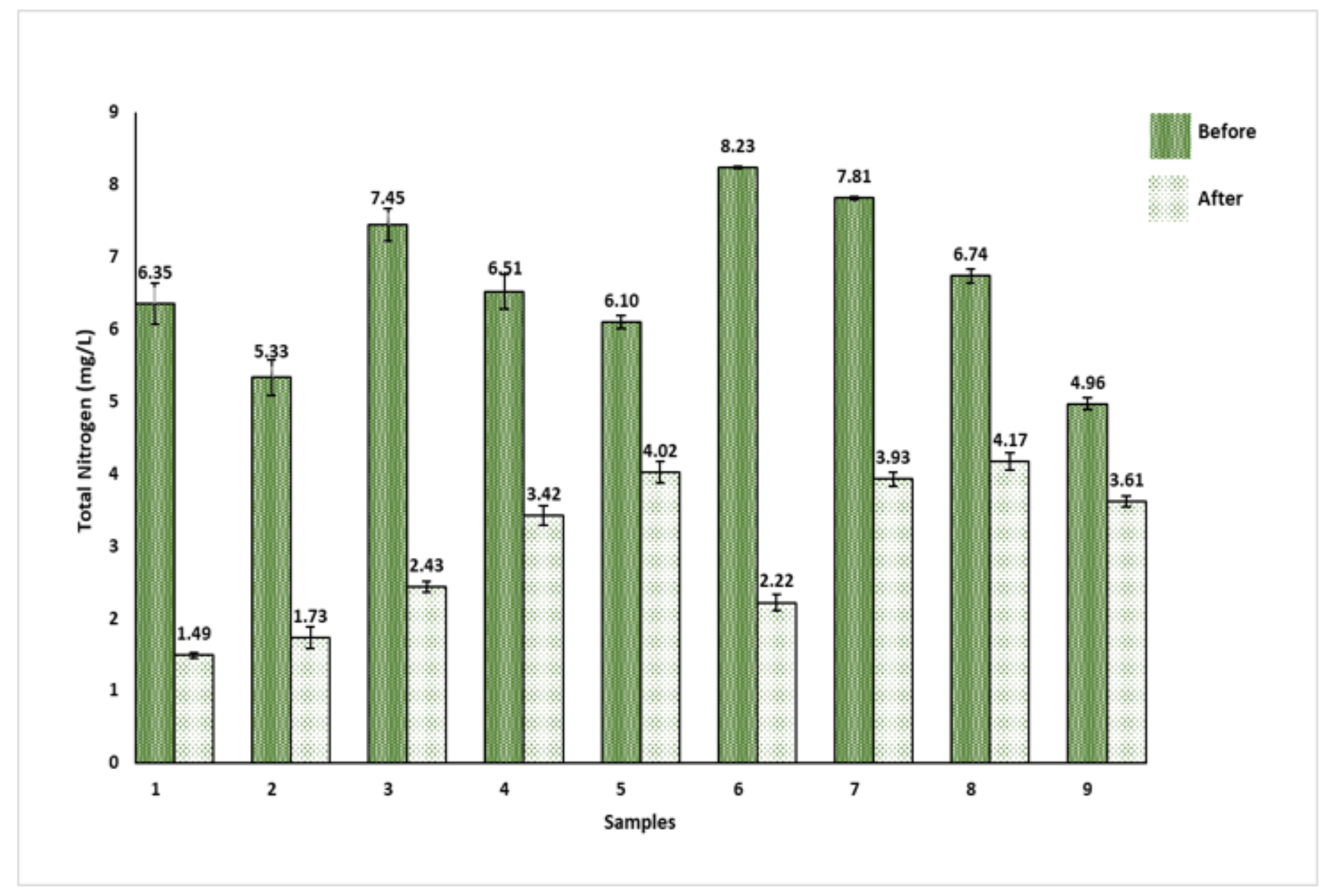

Figure 4

Total nitrogen content of wastewater samples before and after cultivation of $P$. insigne 


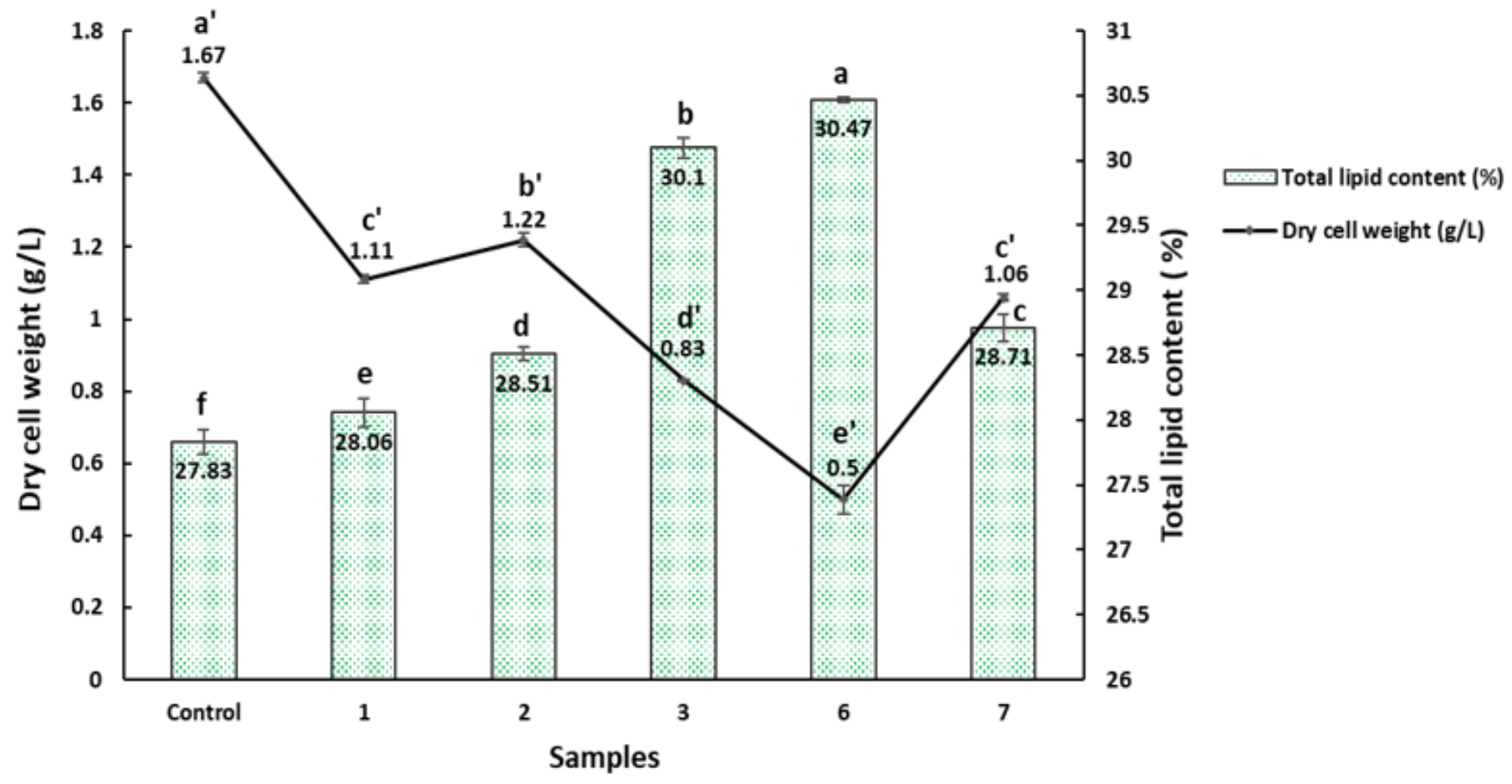

Figure 5

Total lipid content and dry cell weight of P. insigne grown in wastewater samples and control 